\title{
A Molecular Approach for Genotyping of Hepatitis B Virus Using Restriction Pattern Analysis of S Amplicon in Pakistan
}

\author{
Nazish Badar ${ }^{1}$, Umer Farooq ${ }^{2}$, Shafaqat $\mathrm{Ali}^{3}$, Nadia Nisar ${ }^{1}$, Muhammad Abubakar ${ }^{4 *}$, \\ Javed Anwar Qureshi ${ }^{3}$ \\ ${ }^{1}$ Public Health Laboratories Division; Department of Virology, National Institute of Health, Islamabad, Pakistan \\ ${ }^{2}$ National Agricultural Research Centre, Animal Health Laboratories, Animal Sciences Institute, Islamabad, Pakistan \\ ${ }^{3}$ National institute of Biotechnology and Genetic Engineering (NIBGE), Faisalabad, Pakistan \\ ${ }^{4}$ National Veterinary Laboratories, Islamabad, Pakistan \\ Email: "hayee41@gmail.com
}

Received January 25, 2012; revised February 10, 2012; accepted February 25, 2012

\begin{abstract}
Background Hepatitis B virus (HBV) is the major etiological agent causing acute and chronic liver disease worldwide with significant morbidity and mortality. The high genetic variability of $\mathrm{HBV}$ is reflected by eight genotypes (A to $\mathrm{H}$ ), each with a particular geographical prevalence. The global pattern of HBV genotypes is associated with the distribution of human population among the different continents and reflects the patterns of human migrations. Objectives This study was conducted with following objectives: 1) To study the prevalence of HBV genotype in Pakistani population; 2) To assess that the RFLP system is simple, rapid and standardized way of identifying HBV genotype. Study Design \& Method In cross-sectional study design a total of $255 \mathrm{HBV}$ ELISA positive samples were studied in order to identify the most prevalent genotypes in Pakistan. These HBV related patients visited various hospitals in Pakistan at Faisalabad, Lahore and Islamabad. Among these samples, 214 were PCR positive and rest 41 were PCR negative for HBV. S-gene of HBV PCR positive samples was amplified by regular (first round) and nested PCR (second round). Second-round PCR products were digested by Restriction Fragment Length Polymorphism (RFLP). This was carried out using five restriction enzymes (HphI, NciI, AlwI, EarI and NlaIV) that identified the genotype-specific sequences. Results \& Conclusion Among (214) PCR positive samples only genotype C and D were identified in local population with 21 cases (9.81\%) of genotype C and 195 (91.1\%) of genotype D. Hence, the algorithm adopted in this study can be used to identify various HBV genotypes.
\end{abstract}

Keywords: Hepatitis B Virus; HBV Genotypes; Surface Antigen Subtypes

\section{Introduction}

Hepatitis B is a worldwide public health problem and about 500 million persons suffer from this chronic viral infection with more than 400 million chronic carriers, constituting $5 \%$ of the world's population [1]. According to a worldwide survey more people die in one day from this chronic illness than from AIDS in a year [2] and each year one million person's die of HBV related viral diseases [3].

The global prevalence of chronic HBV infection varies from high ( $\geq 8 \%$ in Africa, Asia and Western Pacific) to intermediate $(2 \%-7 \%$ in Southern and Eastern Europe) and low $(<2 \%$ in Western Europe, North America and Australia) $[4,5]$. An estimated $8 \%$ population of South Asia is its carrier [6-8]. However, in Pakistan, HBsAg

${ }^{*}$ Corresponding author. carrier's ranges from $4 \%-10 \%$ and among them $23 \%$ are immune to HBV, while $34 \%$ show evidence of exposure, $3.5 \%$ children and $13 \%$ cases at haemodialysis units are HBsAg positive, respectfully [9].

With the emergence of resistant viral mutants there is a need for developing of new improved molecular assays for diagnosis, treatment and therapy. These techniques have already gained much importance to identify variants with diverge pathological and clinical lesions. In this scenario, genotyping systems using RFLP analysis of S-gene PCR product or pre-S sequence has previously been reported [10].

In this study, S gene was selected, keeping in view, the sequence of S-gene, which is more conserved rather pre-S region, as the former overlaps the active site in the $P$ gene, which is encoded in a different frame [11].

HBV genome is a partially double-stranded circular 
DNA molecule, approximately $3200 \mathrm{bp}$, which encodes four overlapping open reading frames. Its characterization is based on the analysis of S-gene [12], classified genetically into seven genotypes from A to G [13] on the basis of inter-genotypic divergence score of more than $8 \%$ in the complete nucleotide sequence $[12,14-17]$ and $4.1 \%$ intergenotypic divergence when compared with $\mathrm{S}$ gene sequences $[15,17]$. HBV consists of four major serotypes adw, adr, ayw and ayr [12]. These serotypes are predominant in different regions of the world [17] and the major subtype reported in Pakistan is ayw $\mathrm{ay}_{2}$ [9].

It is postulated from the geographical distribution of HBV genotypes that it is originated from America and spread into the old world over the last 400 years after contact from European colonization [18] and theses genotypes would have originated from a common ancestor approximately 2300 - 3100 years ago [19].

Genotype A, although pandemic, is most prevalent in North-West Europe, Urban areas of South Africa [20] and North America [17]; Genotype B belongs to indigenous population of South-East Asia [14,21], mostly in Indonesia, China and Vietnam [16]; Genotype $\mathrm{C}$ is common in China, Japan, Korea and Vietnam [15]; Genotype $\mathrm{D}$ is also pandemic but is still found mostly in Mediterranean and Middle East region [12]; Genotype E is typical for Africa; Genotype $\mathrm{F}$ is present in Polynesia and American natives [22], while a new Genotype G is reported from Atlanta, USA and Lyon, France [17]. No studies were conducted to observe prevalent HBV genotypes in South-East Asia especially in Pakistan, Bangladesh and Sri Lanka.

HBV genotyping may evolve as a research tool into an essential clinical diagnostic test, very much as $\mathrm{HCV}$ genotyping. Only hurdle in the introduction of HBV genotyping to clinical practice is the lack of a simple, rapid and accurate test [23]. Currently, HBV genotypes can be determined by several methods, including direct sequencing [17], restriction fragment length polymorphism analysis [24,11], line-probe assay [25], PCR using type-specific primers [26], colorimetric point mutation assay [27], ligase chain reaction assay [28], and ezymelinked immunosorbent assay for genotype-specific epitopes [29]. Direct sequencing is the most accurate method and permits detection the common as well as uncommon mutations, but is the most expensive and tedious [11]. Developments of rapid, simple and standardized assays which can detect all known genotypes can not only accelerate research process but can be used clinically.

The well-known variations in HBV genotype in different geographic regions of the world prompted us to investigate the frequency of its genotypes in local population of this country. The aim of this study was to establish a simple and accurate HBV genotyping system using RFLP of the small $\mathrm{S}$ gene region, which could identify its genotypes from $\mathrm{A}$ to $\mathrm{F}$.

\section{Material and Methods}

\subsection{Patient's Selection and Collection of Samples}

A total of 255 clinically diagnosed and ELISA confirmed Hepatitis B patients attending or consecutively admitted to either medical or surgical wards at Faisalabad (Allied Hospital and Chiniot Blood Bank), Islamabad (Pakistan Institute for Medical Sciences and Poly Clinic Hospital) and Lahore (Mayo Hospital) were included in this study. Heparinized blood was collected from all these patients and plasma was separated and stored at $-20^{\circ} \mathrm{C}$.

\subsection{Epidemiological Data of Hepatitis B}

Demographic parameters (age, sex, family history of hepatitis B, clinical symptoms, duration of disease); pathological parameters (Alanine amino transferase (ALT) level; associated risk factors for HBV transmission and sero-positivity against its surface antigen) were recorded either by direct interview from the patients or form the hospital record on a pre-designed questionnaire for epidemiological studies of hepatitis B.

\subsection{Laboratory Testing}

ALT of each patient was estimated using routine automated technique, while serum HBsAg was assayed by kit (Ausrria-II and Imx HBe 2.0; Abbott Automated Analyzer). These tests were performed at various pathology laboratories of the respective hospitals at Faisalabad, Islamabad and Lahore.

\subsection{DNA Extraction}

HBV DNA was extracted from plasma using PhenolChloroform following Kao et al. [13].

\subsection{Primers}

Two sets of primers (diagnostic and hepatitis B surface antigen) were used $[11,13]$ based on the most conserved regions derived from the known sequences primers were synthesized from Gibco, BRL \& Fermentas (USA). Primers used for amplification of target sequences of HBV are shown in Table 1.

The diagnostic primers were used to detect the circulating $\mathrm{HBV}$ in the patients for initial conformation; where as HBsAg primers were used to amplify the part of hepatitis B surface antigen genome. The later amplified DNA product was used for HBV genotyping.

\subsection{Hepatitis B Virus Amplification}

HBV DNA was amplified using diagnostic primers by PCR, DNA extracted from all plasma was added to the 
following amplification mixture: $5 \mu$ of 10X PCR buffer, $3 \mu \mathrm{l}$ of $2.5 \mathrm{mM}$ deoxyribonucleotide triphosphate, $0.2 \mu 1$ of Taq DNA polymerase (5 units), $1 \mu \mathrm{l}$ of $50 \mathrm{pM}$ sense (HBV 409) and antisense primers (HBV 703) in a $50 \mu \mathrm{l}$ reaction volume. The amplification profile was $5 \mathrm{~min}$ at $94^{\circ} \mathrm{C}$, followed by 35 cycles at $94^{\circ} \mathrm{C}$ for $30 \mathrm{sec}$ (denaturation), $30 \mathrm{sec}$ at $55^{\circ} \mathrm{C}$ (annealing) and $30 \mathrm{sec}$ at $72^{\circ} \mathrm{C}$ (extension). An amount of $2 \mu \mathrm{l}$ first round PCR product was added to second round PCR mixture having same composition except a different set of inner sense (HBV 485 ) and antisense primers (HBV686). Second round PCR products $(10 \mu \mathrm{l})$ were electrophoresed on $1.5 \%$ agarose gel in $1 \mathrm{X}$ TBE buffer [5X stock TBE: $54.0 \mathrm{~g}$ Trizma base, $270 \mathrm{~g}$ Boric acid, $20 \mathrm{ml}$ EDTA (0.5 M, pH 8.0)] [30], stained with ethidium bromide (Et.Br. solution 0.5 $\mu \mathrm{g} / \mathrm{ml}$ ). The samples were visualized under ultraviolet illuminator at a wavelength of $254 \mathrm{~nm}$ using Eagle Eye Gel documentation system (Stratagene, USA). A known negative and positive serum control was also included in each run to ensure specificity.

\subsection{HBV Genotyping by RFLP Analysis}

A genotyping system was designed in which RFLP using DNA primers targeting conserved part of HBV surface antigen gene were synthesized from nucleotide 58 to 732 bp (5' to 3'). After identifying the genotype-specific restriction enzyme sequences, viral DNA extracted from the 214 positive sera using diagnostic PCR external sense, (HBMF1) and antisense primers, (HBMR1) and a second round (inner sense, (HBMF2) and antisense primers, (HBV 703). The amplification profile used in diagnostic PCR was 5 min at $95^{\circ} \mathrm{C}$, followed by 30 cycles at $94^{\circ} \mathrm{C}$ for $45 \mathrm{sec}$ (de-naturation), $45 \mathrm{sec}$ at $60^{\circ} \mathrm{C}$ (annealing) and
$45 \mathrm{sec}$ at $72^{\circ} \mathrm{C}$ (extension) with a final extension at $72^{\circ} \mathrm{C}$ for 5 minutes followed by nested PCR with same profile except with an annealing temperature of $45 \mathrm{sec}$ at $61^{\circ} \mathrm{C}$. Positive and negative controls were also included in PCR analysis.

HBV genotypes were identified using PCR-RFLP of nested PCR (2nd Round) product. The positive nested PCR amplicons were restricted independently using five restriction enzymes (AlwI, EarI, HphI, NciI and NlaIV; New England BioLabs). Restriction digestions were carried out using $7 \mu 1$ of the nested PCR product with $5-10$ units of the restriction enzymes (New England BioLabs) following adjustment with $10 \mathrm{X}$ enzyme buffer at $37^{\circ} \mathrm{C}$ for 3 - 4 hour in $20 \mu \mathrm{l}$ reaction volume. The enzyme digested PCR products were electrophoresed on $2 \%$ agarose gel and stained for examination of RFLP pattern under ultraviolet illuminator.

\subsection{Statistical Analysis}

The electronic database organized in the Statistical Package for Social Sciences (SPSS) for windows (version 15.0). The results were expressed as means $\pm \mathrm{SD}$ or as percentages. Mean \pm S.D was calculated for age, disease duration and ALT levels. Frequencies and percentages were calculated for gender and HBsAg. The Pearson's chi-square test was applied to check the association of genotypes between gender and HBsAg. Independent sample t-test was used to check association of age, disease duration and ALT with genotypes. In order to identify age, gender, ALT levels and HBsAg associated to genotypes, simple logistic regression (Enter method) calculated at $\mathrm{P}<0.05$ with $95 \%$ confidence levels. The prediction model was validated by Receiver

Table 1. Primers used for amplification of target sequences of $\mathrm{HBV}$.

\begin{tabular}{|c|c|c|c|c|c|}
\hline Amplicon & Sequence $\left(5^{\prime}-3^{\prime}\right)$ & Sense/Antisense ${ }^{a}$ & Position $n t^{b}$ & $\begin{array}{l}\text { Amplicon } \\
\text { Size (bp) }\end{array}$ & References \\
\hline $\begin{array}{l}\text { Diagnostic Set } 1 \text { (Regular) } \\
\text { Forward primer } \\
\text { Reverse primer }\end{array}$ & $\begin{array}{c}\text { HBV } 409 \text { (Surface antigen) } \\
\text { 5'CAT CCT GCT GCT ATG CCT CAT CT 3' } \\
\text { HBV } 703 \\
\text { 5'CGA ACC ACT GAA CAA ATG GCA CT 3' }\end{array}$ & AS & $\begin{array}{l}5^{\prime} 283 \text { to } 3053^{\prime} \\
5^{\prime} 556 \text { to } 5783^{\prime}\end{array}$ & 296 bp & {$[13]$} \\
\hline $\begin{array}{l}\text { Set } 2 \text { (Nested) } \\
\text { Forward primer } \\
\text { Reverse primer }\end{array}$ & $\begin{array}{c}\text { HBV } 485 \text { (Surface antigen) } \\
\text { 5'GGT ATG TTG CCC GTT TGT CCT CT 3' } \\
\text { HBV } 686 \\
\text { 5'GGC ACT AGT AAA CTG AGC CA 3' }\end{array}$ & AS & $5^{\prime} 332$ to $3543^{\prime}$ & $230 \mathrm{bp}$ & \\
\hline $\begin{array}{l}\text { HBsAg Set } 1 \text { (Regular) } \\
\text { Forward primer } \\
\text { Reverse primer }\end{array}$ & $\begin{array}{c}\text { HBMF1 (Surface antigen) } \\
\text { 5'CCT GCT GGT GGC TCC AGT TC 3' } \\
\text { HBMR1 } \\
\text { 5'TTC GGT TTG TCA CCC CCT TTC G3' }\end{array}$ & AS & $5^{\prime} 58-773^{\prime}$ & $675 \mathrm{bp}$ & \\
\hline $\begin{array}{l}\text { Set } 2 \text { (Nested) } \\
\text { Forward primer } \\
\text { Reverse primer }\end{array}$ & $\begin{array}{c}\text { HBMF2 (Surface antigen) } \\
\text { 5'GTC TAG ACT CGT GGT GGA CTT CTC TC3' } \\
\text { HBV703 } \\
\text { 5'CGA ACC ACT GAA CAA ATG GCA CT 3' }\end{array}$ & AS & $\begin{array}{l}5^{\prime} 248-2733^{\prime} \\
5^{\prime}, 707 \text { to } 6843^{\prime}\end{array}$ & 459 bp & [11] \\
\hline
\end{tabular}

${ }^{\mathrm{a}} \mathrm{S}$, sense; AS, antisense; ${ }^{\mathrm{b}}$ The nucleotide position is based on the hepatitis B virus adr subtype. 
Operating Characteristic Curve (ROC).

\section{Results}

\subsection{RFLP Patterns/Genotype Distribution}

The sequence of prevalent HBV strain $\left(\mathrm{ayw}_{2}\right)$ in Pakistan was inspected to ascertain the restriction sites that can be identified corresponding to genotype-specific sequences. Five restriction enzymes, $H p h \mathrm{I}, N c i \mathrm{I}, A l w \mathrm{I}, \operatorname{EarI}$ and NlaIV, were identified suitable for yielding restriction patterns that could identify six HBV genotypes-specific RFLP from the $\mathrm{S}$ gene region (Figure 1). Genotype $\mathrm{B}$ could be distinguished by the fact that $\mathrm{S}$ gene fragment remained uncut by EarI, while no $A l w I$ site was present in $\mathrm{S}$ gene sequences for genotype $\mathrm{C}$ and this restriction pattern was observed in 21 samples. Genotype E had a restriction site for $\mathrm{Nci}$ I at nucleotide position 353, cutting the $\mathrm{S}$ gene into two fragments of 353 and $106 \mathrm{bp}$ in length. Enzyme HphI has restriction site nucleotide position 412, which is the site for genotype F. All genotype D sequences could be distinguished by the fact that $\mathrm{S}$ gene had a unique NlaIV site at nucleotide position 186, which gave two characteristic bands of 186 and $273 \mathrm{bp}$ in length. A NlaIV site at nucleotide position 186 and 273 bp was observed in 193 samples. Moreover, PCR products of genotype A could be digested at nucleotide position 220 by specific restriction enzyme NlaIV, no band was observed at position 299 (Figure 1). This revealed genotyping based on PCR-RFLP using an amplicon of HBV $\mathrm{S}$-gene positive isolates showing predominant genotype $\mathrm{C}$ and $\mathrm{D}$ with $9.8 \%$ and $90.2 \%$, respectively. No other genotypes were observed in this study.

\subsection{Comparison of Demographic and Clinical Characteristics among HBV Genotypes}

A total of 255 hepatitis B, ELISA positive samples were analyzed by PCR for the detection of HBV surface antigen. Out of theses samples $214(84 \%)$ were positive by PCR. The percent prevalence of the genotypes $\mathrm{C}$ and $\mathrm{D}$ was $10 \%$ (21) and $90 \%$ (193) as determined by PCRRFLP, respectively.

The genotype $\mathrm{C}$ was observed in 12 (57\%) males and $9(43 \%)$ females with age in years $47.6 \pm 11$, while genotype D was found in $151(78 \%)$ males and $42(22 \%)$ females with age in years $34.5 \pm 12.3$. Univariate logistic analysis of genotypes showed no significant relationship with age $(\mathrm{P}>0.05, \mathrm{OR}=0.998)$ and gender $(\mathrm{P}>0.05$, $\mathrm{OR}=2.413$ ) presented in Table 2 .

The duration of disease in months between genotype $\mathrm{C}$ and $\mathrm{D}$ was no significant and it was $8.8 \pm 2.2$ for genotype $\mathrm{C}$ and $10.6 \pm 12$ for genotype $\mathrm{D}$. The frequency distribution of HBsAg positive cases of genotype $\mathrm{C}$ and $\mathrm{D}$ was $21(100 \%)$ and $184(95 \%)$, respectively and no sig-

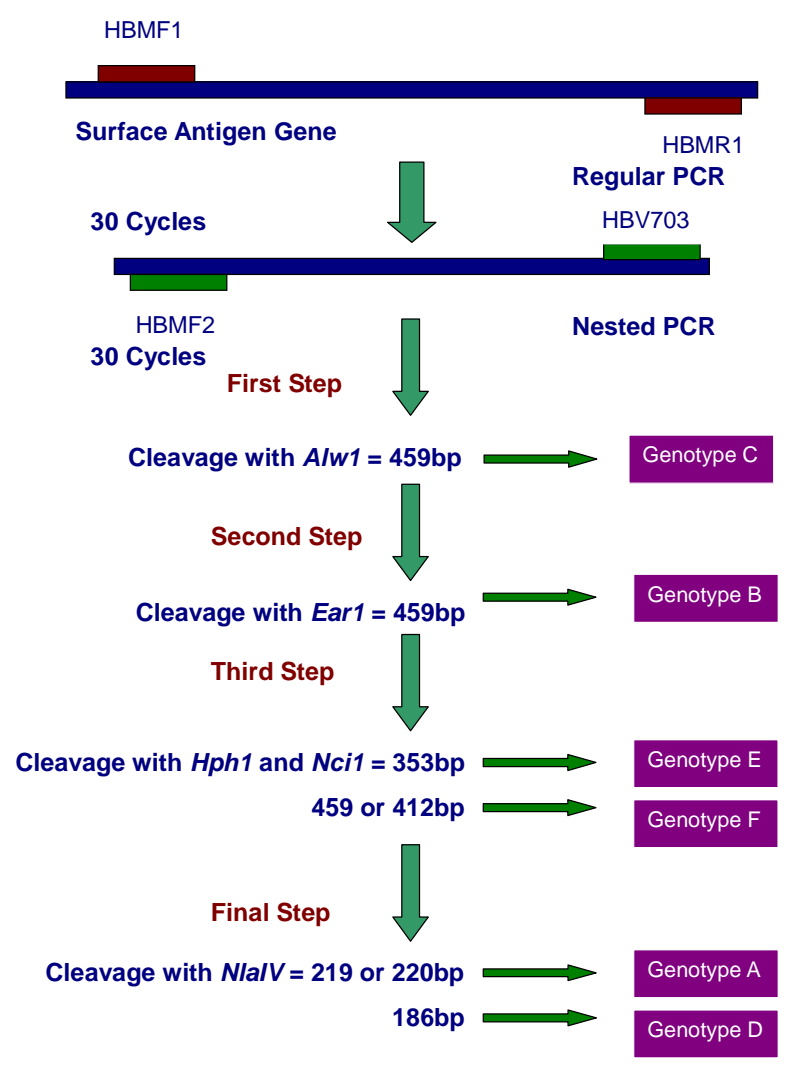

Figure 1. Strategy of the HBV genotyping by RFLP.

nificant difference was observed in frequency distribution of these genotypes (Table 2).

A significant difference was observed between molecular features of the cases depending on the genotype $\mathrm{C}$ and $\mathrm{D}(\mathrm{P}<0.001)$. The frequency distribution of positive cases during first round PCR of genotype C and D were $21(100 \%)$ and $63(32.6 \%)$, respectively, while only 130 $(63.3 \%)$ cases of genotype D were found positive in second round PCR (Table 2).

\subsection{Genotypes and Serum ALT}

Levels of ALT (U/L) varied from 16 to 430 and 370 490 for genotype C and D respectively, ALT values were 11 and 3.7 times higher, when compared with normal values (452 U/L; $152 \mathrm{U} / \mathrm{L})$. Significant difference was observed in frequency distribution of these genotypes and the value of by using student t-test $(\mathrm{p}=0.007)$ presented by Table 2 .

The univariate logistic analysis revealed genotype D has an independent association with high level of ALT (P $=0.001, \operatorname{Exp}(\mathrm{B})=1.022)$ shown in Table 3 .

The area under the Receiver Operating Characteristic Curve (ROC) resulting from this predicting variable Serum ALT (U/L) (genotype C and D) was 0.95 (95\% Confidence interval of ROC: 0.919 - 0.983) as shown in Figure 2. 
Table 2. Baseline characteristics of patients infected by HBV genotype C or D.

\begin{tabular}{|c|c|c|c|}
\hline \multirow{2}{*}{ Parameters } & \multicolumn{2}{|c|}{ Patients Infected with HBV } & \multirow{2}{*}{ P-value } \\
\hline & Genotype C $(\mathrm{n}=21)$ & Genotype D $(n=193)$ & \\
\hline $\begin{array}{l}\text { Age (yr) } \\
\text { Range }\end{array}$ & $\begin{array}{c}47.6 \pm 11 \\
34-62\end{array}$ & $\begin{array}{c}34.5 \pm 12.3 \\
\quad 8-65\end{array}$ & NS \\
\hline $\begin{array}{l}\text { Serum ALT (U/L) } \\
\text { Range }\end{array}$ & $\begin{array}{c}452 \pm 47.6 \\
370-490\end{array}$ & $\begin{array}{c}152.1 \pm 12.3 \\
16-430\end{array}$ & $0.007 *$ \\
\hline Disease duration & $8.8 \pm 2.2$ & $10.6 \pm 12$ & NS \\
\hline \multicolumn{4}{|c|}{ Gender (n, \%) } \\
\hline Male & $12(57)$ & $151(78)$ & \\
\hline Female & $9(43)$ & $42(22)$ & NS \\
\hline Male: female ratio & $4: 3$ & $5: 1$ & \\
\hline \multicolumn{4}{|c|}{ HBsAg (n, \%) } \\
\hline Positive & $21(100)$ & $184(95)$ & \multirow{2}{*}{ NS 0.604} \\
\hline Negative & - & $9(5)$ & \\
\hline \multicolumn{4}{|c|}{ PCR Positive (n, \%) } \\
\hline First-round & $21(100)$ & $63(32.6)$ & \multirow{2}{*}{0.001} \\
\hline Second-round & - & $130(63.3)$ & \\
\hline
\end{tabular}

NS: Not significant; ALT: Alanine aminotransferase.

Table 3. Logistic regression analyses of HBV genotypes according to Age, Gender, Serum ALT (U/L), HBsAg and PCR.

\begin{tabular}{ccccccc}
\hline \multirow{2}{*}{ Parameters } & $\beta$-Coefficient & \multicolumn{2}{c}{$95 \%$ CI } & \multirow{2}{*}{ Odds Ratio } & P-value \\
\cline { 3 - 4 } & & Lower & Upper & & 0.891 \\
Age & -0.002 & 0.964 & 1.033 & 0.998 & 0.098 \\
Gender (referent: female) & 0.881 & 0.850 & 6.851 & 2.413 & 0.001 \\
Serum ALT (U/L) & 0.022 & 1.013 & 1.032 & 1.022 & 0.765 \\
HBsAg (referent: negative) & -0.032 & 0.001 & 0.003 & 0.002 & \\
\hline
\end{tabular}

\subsection{Age Group Specific Prevalence of HBV Genotypes}

The prevalence of HBV infection 59 (27.5\%) for PCR positive patients was more common in age group 40 - 49 years as shown in Figure 3. This infection was more common in $39(31 \%)$ males as compared to 20 females (23\%). Prevalence of HBV was highest in females 27 $(30.68 \%)$ aged 30 - 39 years as compared to 28 males $(22 \%)$ of same age group presented in Table 4 . The highest percentage of genotype $\mathrm{C}$ and $\mathrm{D}$ were 7 (33.3\%) and $52(26.94 \%)$, respectively in age group $40-49$ years. Genotype C was not observed in age group $1-9$, while genotype D was $5(2.59 \%)$ in this age group.

The highest number of HBV 17 patients (32.69\%) by regular PCR was in age group $40-49$ years and 47 patients $(29.01 \%)$ by nested PCR in age group $30-39$.

Interestingly the patients with increased ALT (higher than $200 \mathrm{U} / \mathrm{L}$ ) were positive for HBV DNA in first round PCR, whereas patients with ALT $\leq 200 \mathrm{U} / 1$ were positive in second round PCR. A significant difference $(p=0.04)$ was observed when chi-square test was applied.

\section{Discussions}

Hepatitis B virus is a global health problem; nearly to billion people have been found with this menace. In addition to its serological classification, HBV isolates are characterized into nine subtypes according to the antigenic determinants of their HBsAg [31,32], a genetic classification based on the comparison of complete genomes has recently defined seven genotypes (A to $G$ ).

In this regard, a simple genotyping system depending on RFLP of surface gene of HBV, which could identify all known genotypes in local population, was developed, which is less complicated as compared to direct sequencing and sequence analysis, additionally it is more economical and less time consuming. In future, this simple and exact genotyping system can help to evaluate the etiological or clinical relevance of HBV genotypes and to predict the progression of liver disease or to investigate routes of infection [11]. 
Table 4. Demographic and clinical data of hepatitis B virus with genotypes $\mathrm{D}$ and $\mathrm{C}$ infection by different age groups $(\mathrm{n}=$ 214).

\begin{tabular}{|c|c|c|c|c|c|c|c|}
\hline \multirow{2}{*}{ Parameters } & \multicolumn{7}{|c|}{ HBV Exacerbation Age Groups } \\
\hline & $1-9$ & $10-19$ & $20-29$ & $30-39$ & $40-49$ & $50-59$ & $60-69$ \\
\hline No. of patients (n, \%) & 5 & 10 & 30 & 55 & 59 & 35 & 20 \\
\hline \multicolumn{8}{|c|}{ Gender (n, \%) } \\
\hline Male & 3 & 7 & 14 & 28 & 39 & 23 & 12 \\
\hline Female & 2 & 3 & 17 & 27 & 20 & 11 & 8 \\
\hline \multicolumn{8}{|c|}{ HBV genotypes (n, \%) } \\
\hline Genotype D & 5 & 9 & 26 & 50 & 52 & 32 & 19 \\
\hline Genotype C & 0 & 1 & 4 & 5 & 7 & 3 & 1 \\
\hline \multicolumn{8}{|c|}{ PCR positivity (n, \%) } \\
\hline First-round & 1 & 1 & 10 & 8 & 17 & 11 & 4 \\
\hline Second-round & 4 & 9 & 20 & 47 & 42 & 24 & 16 \\
\hline Serum ALT Mean \pm SD & 250 & $164 \pm 5.6$ & $123 \pm 93.1$ & $147 \pm 145$ & $235 \pm 174$ & $271 \pm 185$ & $263 \pm 92.9$ \\
\hline
\end{tabular}

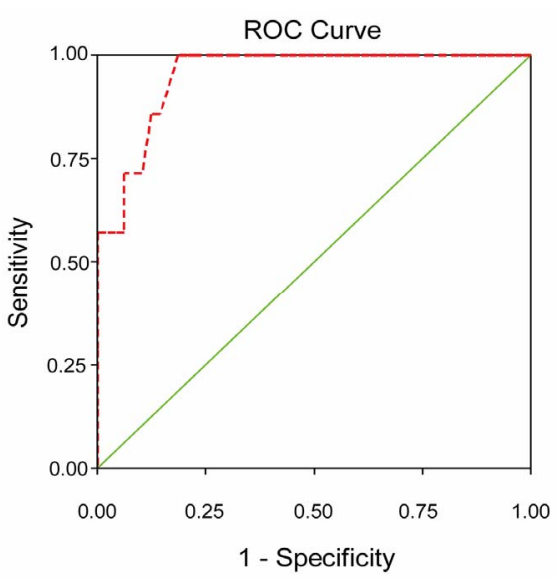

Figure 2. Diagonal segments are produced by ties.

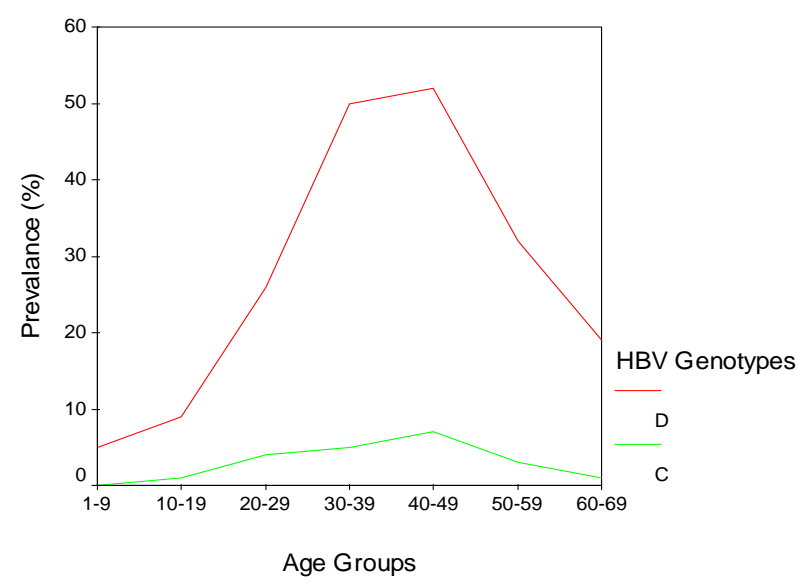

Figure 3. Prevalance of HBV genotypes by age groups.

It was observed that male plays an important role in the acquisition of infection. The prevalence HBV was higher in males (69\%) as compared to females (41\%). It was significantly higher in age higher than 30 years. Most affected patients were men aging 40 years or older and the possible explanation for this may be their more exposure to the risk factors [33]. It was observed that early aged patients, who were positive for HBV DNA, showed comparatively low levels of the ALT. Early life is immune tolerance to $\mathrm{HBV}$ with normal serum ALT levels, despite HBV DNA levels [33].

Patients with $\mathrm{HBsAg}^{+}$and elevated ALT (higher than $200 \mathrm{U} / \mathrm{L}$ ) were found positive for HBV DNA in first round PCR but a second round PCR was required for patients with ALT levels $<200 \mathrm{U} / 1$. Similar results were also reported [34]. It is assumed, the patients positive in the first round PCR have high viral load.

Researchers are just only starting to look at HBV genotyping as a clinical management tool [35]. There is increasing evidence that the clinical picture, response to treatment and long-term prognosis may differ among individuals depending on genotype. Usually, HBV genotyping is based upon sequence variability of S-gene $[11,12,15,17]$.

A RFLP pattern was studied at HBV S-region sequence of Pakistani isolates. This sequence is more conserved than pre-S region, because it overlaps the reverse transcriptase active site in the $\mathrm{P}$ gene, which is encoded in a different frame [11]. Genotype D $(90.2 \%)$ is the major and $\mathrm{C}(9.8 \%)$ is minor genotype in Pakistan, while genotype $\mathrm{A}, \mathrm{B}, \mathrm{E}$ and $\mathrm{F}$ were not found. However, it is possible that some minor HBV genotypes may be present in a local population besides major genotypes, as few genotypes are pandemic including genotype A and even some mosaics as well as novel or distinct groups also exists $[10,12]$. The current study revealed that RFLP is 
relatively a simple but accurate method that can widely be used for HBV clinical and etiological research.

Genotype distribution pattern among patients with different ages was also observed and the prevalence of genotype $\mathrm{C}$ was more in age group $>35$ years but genotype D was widely distributed among all age groups and similar observations were reported [37]. Some pathological differences may also exist among different genotypes.

Regarding clinical and biochemical implications in patients the significant differences $(P=0.04)$ were observed in genotype $\mathrm{C}$ and $\mathrm{D}$ relating to ALT level. Patients with genotype $\mathrm{C}$ had elevated ALT level as compared to genotype $\mathrm{D}$ (452 vs $152.1 \mathrm{U} / \mathrm{L})$, suggesting that genotype $\mathrm{C}$ is associated with the severity of liver diseases and it plays an important role in the development of such diseases when compared to genotype D [38]. Severe liver damage (ALT) has been reported [26] with genotype $\mathrm{C}$ and the patients have higher serum viral DNA level $(>200 \mathrm{Pg} / \mathrm{ml})$ and much higher serum ALT level as compared to patients with genotype $\mathrm{D}$, showing more inflammation and fibrosis reflective of sever liver disease.

Moreover, patients with $\mathrm{C}$ genotype were diagnosed in first round PCR as compared to genotype D. It suggests that genotype $\mathrm{C}$ yield a higher HBV DNA level than genotype D and same was observed [16,39].

Among all the PCR positive samples $(\mathrm{n}=214) 96 \%$ were also found positive for HBsAg. All the PCR positive genotype $\mathrm{C}$ samples were also found positive for HBsAg. In case of genotype D 95\% samples were positive for $\mathrm{HBsAg}$, while rest $5 \%$ was $\mathrm{HBsAg}$ negative. In Pakistan HBsAg carrier rate varies from 4\% - 10\%, 23\% subjects were immune to $\mathrm{HBV}$ and $34 \%$ showed evidence of exposure. Among children $3.5 \%$ were HBsAg positive [9].

Genotype determination helps in managing HBV infections with better diagnosis and adaptation of strategies in diagnostics. Recently it is reported that PCR can identify genotypes at an early stage of infection [26].

\section{REFERENCES}

[1] C. Hannoun, P. Horal and M. Lindh, "Long Term Mutation Rates in the Hepatitis B Virus Genome," Journal of General Virology, Vol. 81, No. 1, 2000, pp. 75-83.

[2] N. Khanna, D. Sahal, S. Swaminathan, K. R. Baba, E. Alalan, A. Chauhan, D.A. Chugh, M. Malhotro and J. Singh, "Mammalian Biology: Recombinant Gene Product," International Centre for Genetic Engineering and Biotechnology, Trieste, 1997.

[3] J. M. Francis, "Updates on Diagnosis, Management and Prevention of Hepatitis B Virus Infection," Journal of Clinical Microbiology, Vol. 12, No. 2, 1999, pp. 355-366.

[4] V. A. Mahoney, J. L. Lopez, P. F. Talenta, G. Palacios, I. Badia, A. Ferro, C. Galoppo and R. Campos, "Distribution of Hepatitis B Virus Genotypes in Two Different Pediatric Populations from Argentina," Journal of Clinical
Microbiology, Vol. 36, No. 11, 1999, pp. 3362-3365.

[5] V. A. Mahoney, J. Francis and K. Mark, "Vaccines," 3rd Edition, Orenstein editors Company, Philadelphia, 1999.

[6] M. Lindh, A. S. Andersson and A. Gusdal, "Genotypes nt, 1858 Variants and Geographic Origion of Hepatitis B Virus, Large Scale Analysis Using a New Genotyping Method," Journal of Infectious Diseases, Vol. 175, No. 6, 1997, pp. 1285-1293. doi:10.1086/516458

[7] M. Lindh, P. Horal, A. P. Dhillon and G. Norkans, "Core Promoter Mutation and Genotypes in Relation to Viral Replication and Liver Damage in East Asian Hepatitis B Virus Carriers," Journal of Infectious Diseases, Vol. 179, No. 4, 1999, pp. 775-782. doi:10.1086/314688

[8] World Health Organization, "IARC Monographs on the Evaluation of Carcinogenic Risks to Humans," Hepatitis Viruses, Vol. 59, 1994, p. 45.

[9] S. J. Zuberi, "An Overview of HBV/HCV in Pakistan," Journal of the Pakistan Medical Association, Vol. 37, 1998, pp. 12-17.

[10] B. Weber, W. Melchior, R. Gehrke, H. W. Doerr, A. Berger and H. Rabenau, "Hepatitis B Virus Markers in Anti $\mathrm{HBc}$ Only Positive Individuals," Journal of Medical Virology, Vol. 64, No. 3, 2001, pp. 312-319. doi:10.1002/jmv.1052

[11] M. Mizokammi, T. Nakano, E. Orito, Y. Tanaka, H. Sakugawa, M. Mukaide and B. H. Robertson, "Hepatitis B Virus Genotype Assignment Using Restriction Fragment Length Polymorphism Patterns," FEBS Letters, Vol. 450, No. 1, 1999, pp. 66-71. doi:10.1016/S0014-5793(99)00471-8

[12] S. M. Bower and G. M. Sim, "Relationship within and between the Genotypes of Hepatitis B Virus at Point across the Genome: Footprints of Recombination in Certain Isolates," Journal of General Virology, Vol. 81, No. 2, 2000, pp. 379-392.

[13] J. H. Kao, N. H. Wu, P. J. Chen, M. Y. Lai and D. S. Chen, "Hepatitis B Genotypes and the Response to Interferon Therapy," Journal of Hepatology, Vol. 33, No. 11, 2000, pp. 998-1002. doi:10.1016/S0168-8278(00)80135-X

[14] H. Okamoto, F. Tsuda, H. Sakugawa, R. I. Sastrosoewignjo, M. Imai, Y. Miyakawa and M. Mayumi, "Typing Hepatitis B Virus by Homology in Nucleotide Sequence: Comparison of Surface Antigen Subtypes," Journal of General Virology, Vol. 69, No. 10, 1988, pp. 2575-2583. doi:10.1099/0022-1317-69-10-2575

[15] H. Norder, B. Hammas, S. Lofdhal, A. M. Courouce and L. O. Magnius, "Comparison of the Amino acid Sequence of Nine Different Serotypes of Hepatitis B Surface Antigen and Genomic Classification of the Corresponding Hepatitis B Virus Strains," Journal of General Virology, Vol. 73, No. 5, 1992, pp. 1201-1208. doi:10.1099/0022-1317-73-5-1201

[16] L. O. Magnius and H. Norder, "Subtypes, Genotypes and Molecular Epidemiology of the Hepatitis B Virus Reflected by Sequence Variability of S-Gene," Intervirology, Vol. 38, No. 1-2, 1995, pp. 24-34.

[17] L. Stuyver, S. De-Gendt, C. Van-Geyt, F. Zoulim, M. Fried, R. F. Schinazi and R. Rossau, "A New Genotype of 
Hepatitis B Virus: Complete Genome and Phylogenetic Relatedness," Journal of General Virology, Vol. 81, Pt. 1, 2000, pp. 67-74.

[18] Fleeming. "The Origion and Evolution of Hepatitis Virus in Humans," Journal of General Virology, Vol. 82, Pt. 4, 2000, pp. 693-712.

[19] P. L. Bolyky, A. Rambaut, N. Grassly, W. F. Carman and E. C. Holmes, "Hepatitis B Virus Has a Recent New World Evolutionary Origion," Hepatology, Vol. 28, 1997, pp. 765-775.

[20] S. M. Bowyer, L. Van Staden, M. C. Kew and J. G. Sim, "A Unique Segment of the Hepatitis B Virus Group A Genotype Identified in Isolates from South Africa," Journal of General Virology, Vol. 78, No. 7, 1997, pp. 17191729.

[21] K. Kidd-Ljunggren, M. Oberg and A. H. Kidd, "The Hepatitis B Virus X Gene: Analysis of Functional domain Variation and Gene Phylogeny Using Multiple Sequences," Journal of General Virology, Vol. 76, No. 9, 1995, pp. 2119-2130. doi:10.1099/0022-1317-76-9-2119

[22] C. Van Geyt, S. De-Gendt, A. Rombout, A. Wyseur, G. Maertens, R. Rossau and L. Suyver, "A Line Probe Assay for Hepatitis B Virus Genotypes,” In: R. F. Schinazi, J. P. Sommadossi, H. C. Thomas, Eds, In Therapies for Viral Hepatitis, International Medical press, London, 1998, pp. 139-145.

[23] M. Hussain, C. Chu, E. Sablon and A. S. F. Lok, "Rapid and Sensitive Assays for Determination of Hepatitis B Virus (HBV) Genotypes and Detection of HBV Precore and Core Promoter Variants," Journal of Clinical Microbiology, Vol. 41, No. 8, 2003, pp. 3699-3705. doi:10.1128/JCM.41.8.3699-3705.2003

[24] M. Mizokami, E. Orito, K. Ohba, K. Ikeo, J. Y. N. Lau and T. Gojobori, "Constrained Evolution of Hepatitis B Virus with Overlapping Genes," Journal of Molecular Evolution, Vol. 44, 1997, pp. 83-90.

[25] C. Grandjacques, P. Pradat, L. Stuyver, M. Chevallier, P. Chevallier, C. Pichoud, M. Maisonnas, C. Trepo and F. Zoulim, "Rapid Detection of Genotypes and Mutations in the Pre-Core Promoter and the Pre-Core Region of Hepatitis B Virus Genome: Correlation with Viral Persistence and Disease Severity," Journal of Hepatology, Vol. 33, No. 3, 2000, pp. 430-439. doi:10.1016/S0168-8278(00)80279-2

[26] H. Naito, S. Havashi and K. Abe, "Rapid and Specific Genotyping System for Hepatitis B Virus Corresponding to Six Major Genotypes by PCR Using Type-Specific Primers," Journal of Clinical Microbiology, Vol. 39, No. 4, 2001, pp. 1686-1689.

[27] A. L. Ballard and E. H. Boxall, "Colourimetric Point Mutation Assay: for Detection of Precore Mutants of Hepatitis," Journal of Virological Methods, Vol. 67, No. 2, 1997, pp. 143-152. doi:10.1016/S0166-0934(97)00089-X
[28] S. Minamitani, S. Nishiguchi, T. Kuroki, S. Otani and T. Monna, "Detection by Ligase Chain Reaction of Precore Mutant of Hepatitis B Virus," Hepatology, Vol. 25, No. 1, 1997, pp. 216-222. doi:10.1002/hep.510250139

[29] S. H. Usuda, H. Okamoto, K. Iwanari, F. Baba, Y. Tsuda and M. Mayumi, "Serological Detection of Hepatitis B Virus Genotypes by ELISA with Monoclonal Antibodies to Type-Specific Epitopes in the PreS2-Region Product," Journal of Virological Methods, Vol. 80, No. 1, 1999, pp. 97-112. doi:10.1016/S0166-0934(99)00039-7

[30] J. Sambrook, E. F. Fritsch and T. Maniatis, "Molecular Cloning, a Laboratory Manual," 2nd Edition, Gold Spring Harbor Laboratory Press, New York, 1989.

[31] A. M. Courouce-Pauty, J. M. Lemaire and J. F. Roux, "New Hepatitis B Surface Antigen Subtypes inside the Adcategory," Vox Sanguinis, Vol. 35, No. 5, 1978, pp. 304-308. doi:10.1111/j.1423-0410.1978.tb02939.x

[32] K. Nishioka, A. G. Levin and M. J. Simons, "Hepatitis B Antigen, Antigen Subtypes and Hepatitis B Antibody in Normal Subjects and Patients with Liver Disease," Bulletin World Health Organization, Vol. 52, No. 3, 1975, pp. 293-300.

[33] N. Leung, "Treatment of Chronic Hepatitis B: Case Selection and Duration of Therapy," Journal of Gastroenterology and Hepatology, Vol. 17, No. 4, 2002, pp. 409-414. doi:10.1046/j.1440-1746.2002.02767.x

[34] F. Pfeffel, C. Oesterricher, E. Penner, P. Erenci, C. Sillber, R. Fiedler and C. Muller, "Rational Use of Polymerase Chain Reaction Based Detection of Viral Genome in Patients with Serological Marker of Hepatitis B or C Virus Infection," Wiener Klinische Wochenschrift, Vol. 109, No. 1, 1997, pp. 20-24.

[35] C. J. Chu, M. Hussain and A. S. Lok, "Hepatitis B Virus Genotype B Is Associated with Earlier HBeAg Seroconversion Compared to Hepatitis B Virus Genotype C," Gastroenterology, Vol. 122, No. 7, 2002, pp. 1756-1762. doi: $10.1053 /$ gast.2002.33588

[36] A. Muqaddas, "Genetic Variation in Well Characterized Chronic HBV Isolates of Pakistan," Master Thesis, University of the Punjab, Lahore, 2001.

[37] X. Ding, M. Mizokami, G. B. Y, et al., "Hepatitis B Virus Genotype Distribution among Chronic Hepatitis B Virus Carriers in Shanghai, China," Intervirology, Vol. 44, No. 1, 2001, pp. 43-47. doi:10.1159/000050029

[38] J. H. Kao, P. J. Chen, M. Y. Lai and D. S. Chen, "Genotypes and Clinical Phenotypes of Hepatitis B Virus in Patients with Chronic Hepatitis B Virus Infection," Journal of Clinical Microbiology, Vol. 40, No. 11, 2002, pp. 1207-1209. doi:10.1128/JCM.40.11.4068-4071.2002

[39] M. Lindh, P. Horal, A. P. Dhillon and G. Norkans, "Hepatitis B Virus DNA Levels Precore Mutations: Genotypes and Histological Activity in Chronic Hepatitis B," Journal of Viral Hepatitis, Vol. 7, No. 4, 2000, pp. 258-268. doi:10.1046/j.1365-2893.2000.00236.x

\author{
Abbreviations \\ HBV, Hepatitis B Virus; \\ RFLP, Restriction Fragment Length Polymorphism.
}

